\title{
The problems of forming a system of green areas as an ecological framework of a large city (on the example of Kyiv)
}

\author{
Alla Pleshkanovska* \\ Kyiv National University of Construction and Architecture, Land Management and Cadastre Department, 31 Povitroflotskyi Ave., \\ Kyiv, 03680, Ukraine
}

\begin{abstract}
Each large city is characterized by its own unique model of spatial organization of green areas, which form the ecological framework of the city and act as a condition for its balanced ecological development. The article presents results of an analysis of the actual state and preconditions for the formation of a system of green areas of public use of a large city on the example of the city of Kyiv. The model of the ecological framework of Kyiv, in comparison with the models of other European cities, is characterized. The specificity of the spatial organization of the landscaping system is marked by the presence of a powerful water-green diameter in the central part of the city, formed by the valley of the Dnipro River with islands, and a developed peripheral-ring forest park belt. The central and middle densely developed area of the city suffers from a significant lack of green areas for public use. The article formulates urban planning problems completion of the formation of an integrated ecological network of Kyiv, and outlined areas for improving the city's landscaping system.
\end{abstract}

\section{Introduction}

Rapid population growth, human economic activity, and land cover change cause an increase in anthropogenic pressure on the planet's ecosystem, including the depletion of natural resources, global warming and climate change [1]. Awareness of the need to take immediate measures to ensure the preservation of the riches and resources of our world is reflected in the formation of the ideology of sustainable development of mankind. One of the key components of such development is the environmental one. In particular, Goal 15 of the 2030 Agenda for Sustainable Development identifies the need to "Protect, restore and promote the sustainable use of terrestrial ecosystems, sustainable forest management, combating desertification and irreversible land degradation and stopping biodiversity loss".

In turn, global urbanization processes lead to excessive concentration of people in limited areas and the constant expansion of territorial boundaries of urban settlements due to the surrounding natural landscapes. This increases the negative impact on the environment, physical and psychological health [2]. The formation of an ecological network at different hierarchical levels as “... a single territorial system that includes areas of natural landscapes, territories and objects of nature reserves" will help to achieve the goal [1].

At the city level a system of green areas and open water of the city - forests, forest parks, parks, squares, other elements of the system of greenery are an ecological network or ecological framework of the city [3]. The most significant interaction of man and the natural environment is felt it is in cities, due to the high concentration of population (in the world - more than half of humanity, in Ukraine $-69.4 \%$ ). One of the ways to ensure sustainable development of settlements, reduce the negative impact of urbanization on the environment, stop the destruction of natural landscapes is the formation of cities' own ecological network, prevention of unjustified destruction of greenery and development of urban green area provision $[4,5]$.

The natural landscape is an important component of human quality of life [6]. The minimum normatively defined level of green area provision of urban areas is expressed in the area of green areas for 1 person. This figure varies significantly from country to country. Regulatory area of public green area (parks of different functional type and hierarchical planning level, squares and boulevards) ranges from $10 \mathrm{sq} . \mathrm{m} /$ person (Ukraine, Russia) to 20-25 sq.m/person (Germany, USA) [7], and the actual area can reach 60-70 sq.m/person [8]. Other types of green areas are subject to separate normative regulation: urban landscape and recreational areas (forests, forest parks, meadows), green areas of limited use (in residential areas, other functional facilities) and areas of special purposes $[9,10]$.

The subjective perception of the city residents of the adequacy of the greenery level is based not only on the normative and actual indicators of the area of green area per capita [11]. Features of landscape-planning and functional-planning organization of the city territory, specifics of relief, climatic area, presence of significant water objects (part of the sea water area, big river or lake)

\footnotetext{
* Corresponding author: pleshkanovska.am@knuba.edu.ua
} 
within the city are important. City and district parks and squares, which are located within the built-up area of the city, play an extremely important role for residents. Trees, shrubs, water bodies, open green spaces and clean air embody the elements of the natural environment and create a sense of closeness to nature, contribute to the recovery of physical and moral strength [12]. Convenient location and accessibility of green areas are very important for all residents, and especially for the elderly and parents with young children [13]. The formation of the city system of landscaping as close as possible to the person, his place of residence, is one of the main tasks of balanced development of the city.

\section{Materials and methods}

The formation of a system of green areas in the conditions of a large developing city is under the pressure of various vector tendencies. On the one hand - the growth of diversity of functions, population and level of motorization, and, accordingly, the growing need for normatively defined areas of green areas for various purposes; on the other hand - increasing the intensity of development, building density and reducing vacant plots for new elements of the city's landscaping system.

The purpose of this study was to identify the existing urban issues of the existing green area provision system of a large city (on the example of the city of Kiev) as a basis for developing further proposals to create the most attractive and balanced green area system. The research was based on the analysis of theoretical bases and normative regulation of formation of a system of green areas of general use; materials of factual information on indicators of green area provision in Kyiv. The cartographic basis was the materials of the general plans of Kyiv [14, 15]. Also uses some results of the author's sociological survey of Kyiv residents regarding their attitude to the actual state of green area provision [11].

\section{Results}

\subsection{The current state of green area provision in Kiev}

\subsubsection{The actual state of green area provision}

According to the current Master Plan of Kyiv [14], the model of spatial planning organization of the territory was based on the development of new, free from construction, territories outside the city within the boundaries of 2001 . The area of the city was expected to increase from 83.56 thousand hectares to 143.4 thousand hectares $(+74 \%)$ with an actually stable population 2,637 thousand people (2001) to 2,650 thousand people (for the period up to 2020) [14]. The total area of recreational areas of the city was expected to increase from 34.9 thousand hectares to 48.9 thousand hectares, respectively. At the same time, the area of green public areas was expected to increase from 5,289.4 hectares to $7,608.0$ hectares for the period up to 2020 , and the provision rate, respectively, from $20.3 \mathrm{sq} . \mathrm{m} /$ person. up to 28.7 sq.m/person [14] (see Table 1).

Table 1. The main indicators of development of green areas of Kyiv.

\begin{tabular}{|c|c|c|c|c|}
\hline indexes & $\begin{array}{c}\text { status } \\
2001\end{array}$ & \begin{tabular}{|c|} 
Master \\
plan of \\
Kyiv until \\
2020 \\
\end{tabular} & $\begin{array}{c}\text { current } \\
\text { status } \\
(\mathbf{2 0 2 0})\end{array}$ & $\begin{array}{c}\text { increase } \\
(2020 / \\
2001)\end{array}$ \\
\hline $\begin{array}{l}\text { Population, } \\
\text { thousand people }\end{array}$ & 2637 & 2650 & 2965 & $\begin{array}{c}+328 \\
(+12.4 \%) \\
\end{array}$ \\
\hline Total area, ha & 83560 & 143400 & 82640 & $\begin{array}{c}-920 \\
(-1.1 \%)\end{array}$ \\
\hline $\begin{array}{l}\text { Developed } \\
\text { territories, ha }\end{array}$ & 48660 & 94500 & 37610 & $\begin{array}{l}-11050 \\
(-22.7 \%)\end{array}$ \\
\hline $\begin{array}{l}\text { Public greenery } \\
\text { area, ha }\end{array}$ & 5289 & 7608 & 5392 & $\begin{array}{c}+103 \\
(+1.9 \%) \\
\end{array}$ \\
\hline $\begin{array}{c}\text { Landscape and } \\
\text { recreational area, } \\
\text { ha }\end{array}$ & 34900 & 48900 & 45030 & $\begin{array}{c}+10130 \\
(+29.0 \%)\end{array}$ \\
\hline $\begin{array}{c}\text { Population } \\
\text { density, people/ha }\end{array}$ & 31.6 & 18.5 & 35.9 & $\begin{array}{c}+4.3 \\
(+13.6 \%) \\
\end{array}$ \\
\hline $\begin{array}{c}\text { Population } \\
\text { density in the } \\
\text { developed } \\
\text { territories, } \\
\text { people/ha }\end{array}$ & 54.2 & 18.5 & 78.9 & $\begin{array}{c}+24.7 \\
(+45.6 \%)\end{array}$ \\
\hline $\begin{array}{c}\text { Public greenery } \\
\text { area, sq.m/person }\end{array}$ & 20.1 & 28.7 & 18.2 & $\begin{array}{c}-1.9 \\
(-9.5 \%) \\
\end{array}$ \\
\hline $\begin{array}{l}\text { Landscape and } \\
\text { recreational area, } \\
\text { sq.m/person }\end{array}$ & 132.3 & 184.5 & 151.9 & $\begin{array}{c}+19.6 \\
(+14.8 \%) \\
\end{array}$ \\
\hline $\begin{array}{c}\text { Total level of } \\
\text { landscaping, \% }\end{array}$ & 41.8 & 34.1 & 54.5 & $\begin{array}{c}+12.7 \\
(+30.4 \%)\end{array}$ \\
\hline
\end{tabular}

However, the actual territorial development of Kyiv has undergone radical changes in relation to the design decisions of the Master Plan of 2002 (see Fig. 1). The actual territory of the city is 82,640 hectares [15], of which green areas and recreational areas cover 45.03 thousand hectares (or $54.5 \%$ ), water surfaces 6.1 thousand hectares (or $7.3 \%$ ) [15].

At the same time, the population increased by $12 \%$ compared to the project and reached 2,965 thousand people as of 01.01.2020 [16]. New construction was carried out mainly not in the projected new territories (former suburban areas, which were envisaged to be included in the project boundaries of Kyiv by the current Master Plan), but in the existing urban areas (see Fig. 1). This has led to a significant increase in population density and urban development density (see Table 1).

The area of the territory within Kyiv, which is covered with greenery of all kinds (including garden and country houses) is 45030 hectares or $54.5 \%$ of the city area. A total of 143 parks in Kyiv with a total area of 4,722 hectares, of which 6 objects are specialized and occupy 611.4 hectares (three botanical gardens, Kyiv Zoological Park, National Museum of Folk Architecture and Life, National Complex "Expocenter of Ukraine"). 

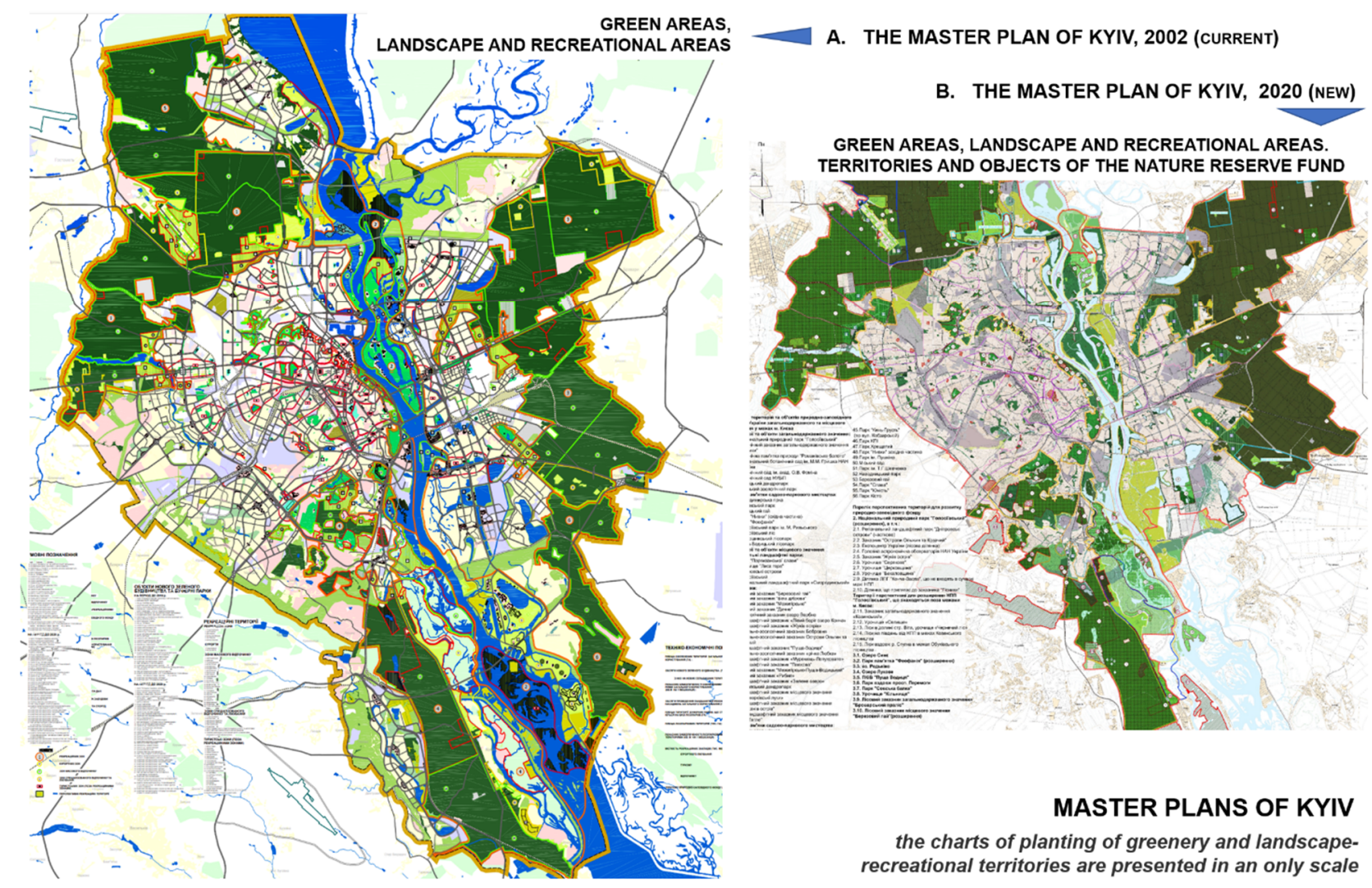

MASTER PLANS OF KYIV

the charts of planting of greenery and landscaperecreational territories are presented in an only scale

Fig. 1. Schemes of spatial development of green and landscape-recreational territories as a part of general plans of Kyiv. A. General plan of Kyiv, 2002 (current, https://kga.gov.ua/generalnij-plan/genplan2020); B. Master plan of Kyiv, 2020 (draft, https://rive.google.com/drive/folders/1HmqVLp25d4PFL08EuLAQ9O8KEFYbhOo5).

Table 2. Characteristics of the actual state of provision of green areas for public use (by administrative districts of Kyiv).

\begin{tabular}{|c|c|c|c|c|c|}
\hline $\begin{array}{c}\text { Administrative } \\
\text { districts }\end{array}$ & $\begin{array}{c}\text { Area, } \\
\text { ha }\end{array}$ & $\begin{array}{c}\text { Population, } \\
\text { persons }\end{array}$ & $\begin{array}{c}\text { Area of public green areas, } \\
\text { ha }\end{array}$ & $\begin{array}{c}\text { Level of landscaping, } \\
\text { \% }\end{array}$ & $\begin{array}{c}\text { Actual landscaping, } \\
\text { sq.m/person. }\end{array}$ \\
\hline Holosiivsky & 15335 & 254331 & 1069.28 & 6.88 & 42.04 \\
\hline Darnytsky & 13160 & 347611 & 473.25 & 3.60 & 13.61 \\
\hline Desniansky & 14210 & 369155 & 532.24 & 3.75 & 14.42 \\
\hline Dniprovsky & 6170 & 358352 & 1118.35 & 18.13 & 31.21 \\
\hline Obolonsky & 10860 & 318968 & 623.41 & 5.74 & 19.54 \\
\hline Pechersky & 2555 & 163264 & 367.72 & 14.51 & 22.52 \\
\hline Podolsky & 3300 & 208449 & 203.15 & 5.97 & 9.75 \\
\hline Svyatoshinsky & 10200 & 342544 & 230.79 & 2.26 & 6.74 \\
\hline Solomyansky & 4010 & 383387 & 282.14 & 7.04 & 7.36 \\
\hline Shevchenkivsky & 2660 & 218952 & 491.91 & 18.61 & 22.47 \\
\hline Kyiv (total) & $\mathbf{8 2 ~ 6 4 0}$ & $\mathbf{2 9 6 5 0 1 3}$ & $\mathbf{5 3 9 2 . 2 4}$ & $\mathbf{6 . 7 7}$ & $\mathbf{1 8 . 1 9}$ \\
\hline
\end{tabular}

At the same time, $50 \%$ of the park areas are occupied by large parks with an area of over 100 hectares (12 objects). In addition, public recreation areas include squares - 582 objects with a total area of 440.7 hectares and boulevards - 49 objects with a total area of 150.7 hectares [15].

According to the monitoring of the Program of development of the green zone of Kyiv until 2010 and the Concept of formation of green area in the central part of the city [17], within which this study was conducted, as of 01.10 .2020 the actual area of green areas is 5392.24 hectares. The average provision in the city is 18.19 sq.m/person (see Table 2), which meets the regulatory requirements for the city of Kyiv 16 sq.m/person. However, there is an uneven provision of green public areas in the city districts. The most prosperous are Holosiivskyi and Dniprovskyi, and the least - Sviatoshynskyi, Solomyanskyi, Podilskyi and Darnytskyi districts of the city. The actual state of green area provision in terms of administrative districts of the city of Kyiv is in the Table 2.

\subsubsection{Analysis of modern practice of transformation of the green area system of Kyiv}

Population growth, the need to increase housing construction, service facilities and places of employment have led to a significant adjustment of the decisions of the current Master plan of Kyiv. Such changes took place by 
approving of detailed plans of the territory for separate parts of the Master plan. According to the city program of development (updating) of urban planning documentation in Kyiv, approved by the decision of Kyiv City Council dated 13.11.2013 № 518/10006 with changes and additions, 152 drafts of detailed plans of territories, as well as zoning plan of central planning zone and zoning plans of other parts of the territory of Kyiv, are under development now. As of the beginning of 2020, the city has approved 42 detailed plans of territories [18] (see Fig. 2).

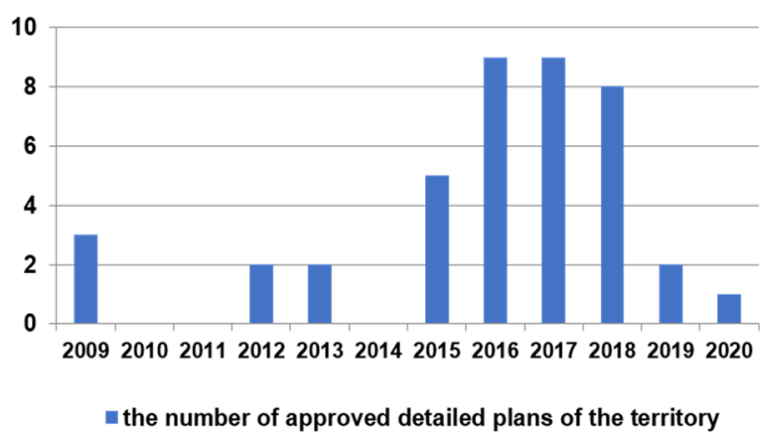

Fig. 2. Dynamics of approval of detailed plans of the territory of Kyiv. Source: data from the Department of Urban Planning and Architecture in Kyiv [18].

There were more than 1,000 changes to the functional purpose of individual land plots taking into account the investment intentions of developers from 2002 to 2011. 1,750 hectares of agricultural land within the city and about 570 hectares of green area have been allocated for construction [15]. Part of the territory really required restructuring due to the suspension of economic activity and degradation of industrial territory and communal warehouses territory. But there is an illegal change of purpose of the land plots of the green area for housing and public building.

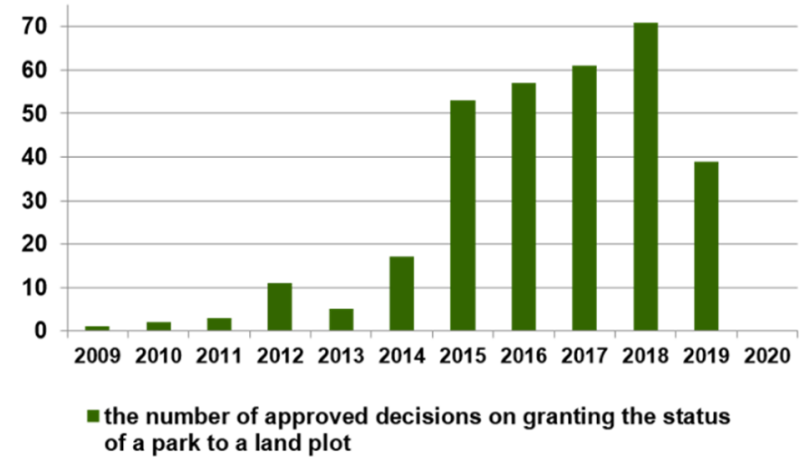

Fig. 3. Dynamics of decision-making on granting the status of a park to a separate green land plot in Kyiv. Source: data of the Kyiv City State Administration [19].

As a compensatory measure and in order to prevent such negative phenomena and excessive compaction of existing housing in the city at the request of deputies of the Kyiv City Council or initiative groups of residents a campaign "to grant the status of a park to land plot" is launched. That is, there is a transfer of green areas of limited use in the category of green areas of public use. There were about 260 such decisions [19] during the period from 2008 to 2020 (see Fig. 3).

However, granting the status of a park to a small land plot within the existing residential building, which is actually part of the adjacent territory of existing residential buildings, leads only to a formal increase in the area of public green areas by reducing the area of adjacent territories and green areas of limited use consequently. In addition, small green areas (0.1-0.5 hectares) do not allow to form an independent element of the system of public greenery - a full-fledged park or square. Such green area remains available only to a limited number of residents of nearby houses.

\subsubsection{Assessment by Kyiv residents of the adequacy of the level of landscaping of the city territory}

As mentioned above, according to the actual indicators, the level of provision of public green areas in Kyiv is quite sufficient. However, the use of only absolute indicators (area of green area and their share in the total area of the city) or even relative indicators (the level provision of population with green area - sq.m/person.) does not really assess the state of development of landscaping and comfort of the urban environment.

According to the results of a sociological survey conducted by the author [11], the vast majority of respondents in the city $(71 \%)$ expressed a lack of green areas, parks and squares. And among the proposed criteria for assessing the attractiveness of the elements of the landscaping system, residents preferred environmental friendliness (over $80 \%$ of respondents) and accessibility of parks (over $67 \%$ ) [11].

Dissatisfaction of residents with the level of development of the parks and squares system of Kyiv can be explained by the peculiarities of the spatial organization of the city.

The system of greenery of various functional purposes in Kyiv has been formed for several centuries and has a permanent character. Significant influence on the spatial organization is created by such factors as planning dismemberment into the right-bank and left-bank parts with a large area of the Dnieper River with green islands in the central part. The middle zone of the city is intensively used for residential, public and industrialwarehouse construction and is surrounded by a powerful peripheral forest park belt (see Fig. 1, B). It is the unevenness in the localization of green areas in the planning structure of the city and their proximity to places of concentration of the population (places of residence and places of work) that create the feeling of lack of green areas.

Creating new elements of the system of green areas parks and squares, which require significant territorial resources, in the conditions of dense urban development and high cost of land in Kyiv is too problematic. Therefore, increasing the attractiveness and level of improvement of existing elements of the city's green area system should be one of the priorities to provide residents 
with a sense of urban comfort and sufficiency in green areas.

\subsection{Specifics of the spatial planning organization of the system of green areas of Kyiv}

Spatial planning organization of the system of green areas of any city has its own specific features, due to the peculiarities of the landscape and climate, historical and cultural traditions, the functional orientation of economic activity and regulatory requirements. However, each city, especially a large one, tries to ensure the integrity and continuity of the internal ecological framework, supplementing the existing system of urban green areas with new natural and artificial elements.

Any large city is marked by the unique specificity of the spatial planning organization of the system of green areas. However, the formation of the continuity of the landscaping system with the obligatory connection of individual elements of the landscape into a single network of open spaces (even, including the territories near highways) should be a condition for sustainable ecological development of the city [20]. Consider examples of models of the system of public green areas in some foreign cities [20,21].

Thus, the municipal project of Milan "Green Rays" in the conditions of dense construction provides for the tracing of pedestrian and bicycle routes, taking into account the available areas of green public areas of different functional types. Complementing them with new planned landscaping - groups of trees along sidewalks, parks - as objects of potential recreation of pedestrians should form a sense of permanence of landscaping in citizens (see Fig. 4, a) [20].

Madrid's ecological system is formed on the basis of suburban natural elements and the restoration of the Manzanares River, forming a continuous connection with large natural areas - the Sierra de Guadarrama, Cuenca Alta del Manzanares, Mount El Pardo, Del Harama Park and Alameda del Tajo. And the main route M30 in some areas was laid underground to open access to the river as the main element of the natural framework of the city [21, 22] (see Fig. 4, b).

The concept of the organization of open spaces in Berlin is to form a system of several groups of green areas. The first - two "green rings" of artificially created in different years elements of urban landscaping: the inner ring around the densely built-up center of Berlin "Innerer Parkring"; the outer ring is the "Äußere Parkring", which connects the large residential areas of the 70s and 80s. The second - two "green" diagonals "Grüne Achsenkreuz", formed on the basis of the dominant natural elements, green strips about 200 meters wide [23 24] (see Fig. 4, c).

The ecological framework of Krakow includes the most valuable natural areas and cultural landscapes that are subject to protection, and are connected by ecocorridors from individual green areas [25] (see Fig. 4, d). To achieve the goal - the unity of the ecological framework - the Master plan of Krakow provides a change in the purpose of part of the land plots. a) Milan

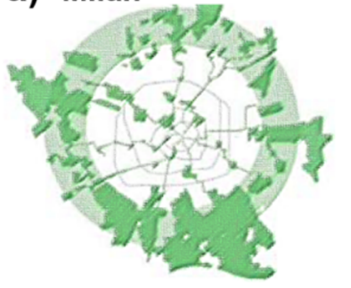

c) Berlin

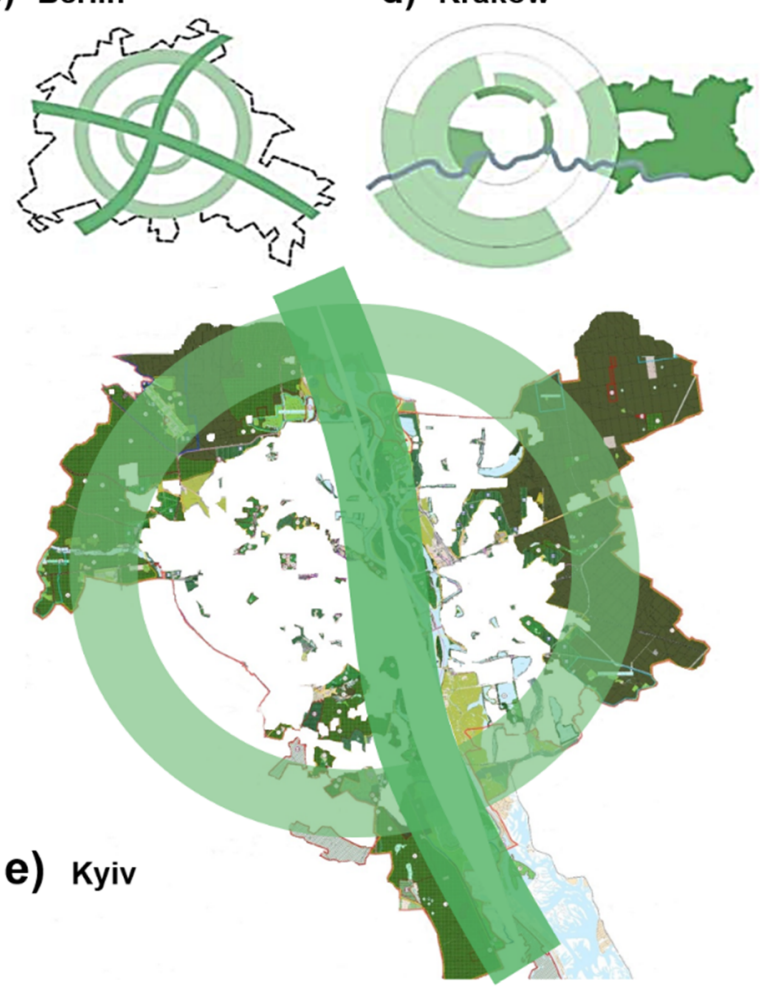

Fig. 4. Examples of ecological framework systems (green and recreational areas) of individual European cities. Sources: a) [20], b) - [21, 22], c) - [23, 24], d) - [25], e) - own model.

Spatial planning organization of green areas of Kyiv, which has developed over a long period of its development, is also characterized by a unique specificity (see Fig. 4, e). The first characteristic feature is the dismemberment of the city, due to the presence of a powerful water-green diameter in the central part. The Dnieper River with a system of islands and green shores with numerous parks. This diameter runs in the meridional direction from north to south and divides the city into two planning parts - Right Bank and Left Bank.

The second feature is the predominant circularperipheral model of green areas in the form of a developed system of forests and forest parks around the densely built-up central and middle zones of Kyiv. Within the built-up areas there are a number of separate parks and squares, which creates difficulties in the availability of green spaces for the vast majority of city residents. The modern spatial planning organization of the system of green and recreational areas is shown in Fig. 1, A. 


\subsection{Urban planning problems of development of the system of green areas of Kyiv}

The analysis of the current state of development of the system of green areas of Kyiv allowed to formulate (from the point of view of urban planning) the following main reasons that negatively affect the ecological conditions and the state of green areas:

- anthropogenic congestion of the urban area, which causes the deterioration of the ecological state of the environment and destructive phenomena in the existence of a system of green areas of the city;

- unsatisfactory sanitary and ecological condition of green plantations and insufficient improvement of park territories;

- lack of territorial resources for the creation of additional regulatory areas of public green areas due to the rapid growth of the population of Kyiv (by 328 thousand people or $12.4 \%$ since 2001) in combination with the virtually unchanged area of city territory;

- specificity of spatial planning organization of the city with a clear central-meridional location of a powerful water-green diameter and external ring-peripheral location of the belt of forests, forest parks, meadows and buffer parks, which creates a sense of inadequate landscaping under the conditions of formal normative provision with green areas;

- exceeding the density of the developed (built-up) territory of the city, which occupies only $46 \%$ of the total area of the city, and alternating the location of residential, industrial, utility and transport areas with relatively small interspersed elements of public green areas, which negatively affects the ecological condition of urban areas in general, and green areas in particular;

- uneven distribution of public green areas by administrative districts;

- incorrectness of the practice of increasing the area of green areas of public use due to green areas of limited use by granting the status of parks to certain areas within the adjacent territories of existing buildings;

- improper use of public green areas;

- the need to develop an integrated system of green areas through the creation of new parks and squares in the territories of former industrial and utility facilities to be redeveloped.

\section{Conclusions}

In conclusion, the strategy of most cities in the world in forming a system of public green areas is to restore, expand and improve the existing network of landscaping, united by creating new elements of green areas into a single ecological framework of the city.

The role of landscape and recreational areas of different origins, nature reserves and green areas of public use in the formation of an integrated system of green areas and the ecological framework of the city differs. If natural objects are the basis of the city's natural planning framework, then objects of artificial origin (parks, squares, boulevards) can complement, optimize or even form the ecological framework of the city.

Completion of the formation of an integral ecological network of Kyiv, general increase of the level of landscaping and comfort, and, accordingly, attractiveness, creation of convenient accessibility of already existing elements of the system of green areas will contribute to the formation of closeness and sufficiency of green areas, providing sustainable environmental development of the city.

\section{References}

1. B. Verheggen, B. Strengers, J. Cook, R. van Dorland, K. Vringer, J. Peters, H. Visser, L. Meyer. Scientists' Views about Attribution of Global Warming, Environ. Sci. Technol. 48, 8963-8971 (2014). doi:10.1021/es501998e

2. Li. Shushu, M. Yong, Urbanization, Economic Development and Environmental Change. Sustainability 6, 5143-5161 (2014)

3. V.V. Oznamets, G.V. Belokonev. Formation of greenbelts as an environmental protection tool. IOP Conf. Series: Materials Science and Engineering 919 (2020). doi:10.1088/1757-899X/919/6/062050

4. About Basic principles (strategy) of public ecological policy of Ukraine on a period 2030 to. Law of Ukraine,

https://zakon.rada.gov.ua/laws/show/269719?lang=en\#Text (2019)

5. J. Palliwoda, E. Banzhaf, J. Priess. How do the green components of urban green infrastructure influence the use of ecosystem services? Examples from Leipzig, Germany. Landscape Ecology 35, 11271142 (2020). doi:10.1007/s10980-020-01004-w

6. M. Dejeant-Pons. The European Landscape Convention, Florence, 20 October 2000. https://minzp.sk/files/postupy-a-ziadosti/ochranaprirody/medzinarodne-dohovory/o-krajine/6prezentradaeurpy.pdf (2000)

7. A. Pleshkanovska, O. Usova, Some issues of green building in the modern city. Modern problems of architecture and urban planning 6, 331-336 (2014)

8. M. Krzyżaniak, D. Świerk, M. Szczepańska, P. Urbański, Changes in the area of urban green space in cities of western Poland. Bulletin of Geography. Socio-economic Series 39, 65-77 (2018). doi:10.2478/bog-2018-0005

9. DBN B.2.2-12: 2019. Planning and development of territories. State Building Standards of Ukraine. 171 p. (Uarkarhbudinform, Kyiv, 2019) https://dreamdim.ua/wpcontent/uploads/2019/07/DBN-B22-12-2019.pdf. Accessed 29 Nov 2020

10. Urban planning: Planner's guide, ed. by T.F. Panchenko (Ukrarhbudinformm, Kyiv, 2001), $192 \mathrm{p}$.

11. A. Pleshkanovska. Assessing the level of greening in a major city: subjective and objective evaluation on 
the example of the city of Kyiv. Bulletin of Geography. Socio-economic Series 48, 155-164 (2020). doi:10.1515/29228

12. A. Ćwik, I. Kasprzyk, T. Wójcik, K. Borycka, Attractiveness of urban parks for visitors versus their potential allergenic hazard: A case study in Rzeszów, Poland. Urban Forestry \& Urban Greening 35, 221229 (2018). doi:10.1016/j.ufug.2018.09.011

13. C. Wen, C. Albert, C. Von Haaren. Equality in access to urban green spaces: A case study in Hannover, Germany, with a focus on the elderly population. Urban Forestry \& Urban Greening 55, 126820 (2020). doi:10.1016/j.ufug.2020.126820

14. The Master Plan of Kyiv for the period up to 2020 (current) (Department of Urban Planning and Architecture, Kyiv, 2002), https://kga.gov.ua/generalnij-plan/genplan2020. Accessed 21 Nov 2020

15. The Master Plan of Kyiv. Substantive provisions. Kyiv (Department of Urban Planning and Architecture, Kyiv, 2020), https:/drive.google.com/drive/folders/1HmqVLp25 d4PFL08EuLAQ9O8KEFYbhOo5. Accessed 21 Nov 2020

16. Statistical information. Population (Main department of statistics in Kyiv, 2020), http://www.kiev.ukrstat.gov.ua/p.php3?c=1123\&lan $\mathrm{g}=1$. Accessed 14 Nov 2020

17. Program of complex development of the green zone of Kyiv until 2010 and the concept of formation of green plantations in the central part of the city. Decision of the Kyiv City Council of July 19, 2005 N 806/3381 (2005). Available at: https://ips.ligazakon.net/document/MR050610

18. Detailed plans of the territory. Kyiv (Department of Urban Planning and Architecture, Kyiv, 2020), https://kga.gov.ua/detalni-plani-teritoriji. Accessed 14 Nov 2020

19. Kyiv City Council. Official Website. https://kmr.gov.ua/uk/content/rishennya-kyyivskoyimiskoyi-rady-1779. Accessed 14 Nov 2020

20. S.P. Tupis, Methods of conservation and use of objects of the nature reserve fund in the structure of cities, Dissertation, Lviv Polytechnic National University, 2019. https://lpnu.ua/sites/default/files/2020/dissertation/1 573/dysertaciyatupissp2019vak3.pdf

21. G. Petryshyn, Progressive Environmental theories in the Formation of Today's Madrid. Experience and Prospects of Development of Ukraine cities: Ecological aspects of urban planning 19, 180-190 (2010)

22. Architecture Prize, Madrid Rio (2017). https://architectureprize.com/winners/winner.php?id $=3060$. Accessed 14 Nov 2020

23. Senate Department for Environment, Transport and Climate Protection. Berlin.de (2018). https://www.berlin.de/sen/uvk/natur-und- gruen/landschaftsplanung/20-gruene-hauptwege/. Accessed 12 Nov 2020

24. Landscape program. Species protection program Berlin.de https://www.berlin.de/sen/uvk/natur-undgruen/landschaftsplanung/. Accessed 12 Nov 2020

25. A map of the actual vegetation of the City of Krakow and the designation of the most valuable natural areas, necessary to maintain the balance of the city's ecosystem. Public Information Bulletin (2017). https://www.bip.krakow.pl/?dok_id=20495\&lid=60 0241416\&vReg=2\&vReg=3. Accessed 12 Nov 2020 